\title{
Enhanced Metal Levels in Vegetables and Farm Soil irrigated with Industrial Waste Water
}

\section{KOUSAR YASMEEN ${ }^{1}$; MUHAMMAD ALI VERSIANI ${ }^{1}$; RAFEE ARAIN ${ }^{\mathbf{1}}$; QAMARUL HAQUE ${ }^{1}$; NASIRUDDIN KHAN ${ }^{2}$; SYED ASGHAR ALI ${ }^{1}$; AASHIQ ALI LANGHA $^{3}$}

\author{
${ }^{1}$ Department of Chemistry, Federal Urdu University of Arts, Science and Technology, \\ Gulshan-e-Iqbal Campus, Karachi-75300, Pakistan \\ ${ }^{2}$ Department of Chemistry, University of Karachi-75270, Pakistan \\ ${ }^{3}$ Environmental Protection Agency, Government of Sindh Karachi, Pakistan
}

\begin{abstract}
In water stressed Karachi city, waste water is often used for irrigating vegetables fields. Persistent use of waste water causes accumulation of heavy metals in agricultural soils and vegetables. $\mathrm{Cd}, \mathrm{Cr}, \mathrm{Zn}$ and $\mathrm{Mn}$ act as essential micronutrients but become toxic after crossing threshold values. To study the effect of waste water on heavy metal concentration in vegetables, soil and water an area irrigated separately with waste water and treated water were selected. Concentrations of $\mathrm{Cd}, \mathrm{Cr}, \mathrm{Zn}$ and $\mathrm{Mn}$ in beet, potato and radish were measured by atomic absorption spectrophotometer. The data obtained was tested at $95 \%( \pm 2 \mathrm{~s})$ confidence level for six replicate measurements. The levels of $\mathrm{Zn}$ was found higher in both the treated water and vegetables beet, potato and radish irrigated with treated water but $\mathrm{Mn}$ was higher in industrial waste water and soil irrigated with industrial waste water and treated water. Soil irrigated with treated water contained $\left(\mathrm{mg} . \mathrm{L}^{-1}\right) 0.007$ of $\mathrm{Cd} ; 0.128 \mathrm{Cr} ; 2.672 \mathrm{Mn}$ and $0.714 \mathrm{Zn}$. Soil irrigated with waste water seems to accumulate significant concentration of metals. It showed (mg. $\mathrm{L}^{-1}$ ) 5.85 of $\mathrm{Cd} ; 84.5 \mathrm{Cr} ; 480.3 \mathrm{Mn}$ and $305 \mathrm{Zn}$. Vegetables irrigated with industrial waste water have shown concurrent rise in metal levels. Mn was 0.860 $\mathrm{mg} . \mathrm{L}^{-1}$ in radish, $\mathrm{Cr} 0.320 \mathrm{mg} . \mathrm{L}^{-1}$ in beet and Cd $0.330 \mathrm{mg} . \mathrm{L}^{-1}$ in potato. @ JASEM
\end{abstract}

Quality of wastewater depends on its source, i.e., sewage or industrial effluents (Akan, 2007). The water can contain pollutants including organisms, pathogens, organic matter, oil, grease, inorganics, nutrients, solids and gases in large enough quantity to put at risk public health and the environment; (Agusa, 2006; Jameel, 2006). Suspended solids, heavy metals and organic matter in industrial wastewater produce a synergetic effect; dissociating at lower $\mathrm{pH}$, metals bound to organic matter become mobile and find their way to diverse end users. The quality of water from the Indus river along the main stream that recharges the two lakes that supply water to the city of Karachi, has been sampled (Mirza et al., 2007), (i) at the foothills of the Himalayas; (ii) $100 \mathrm{~km}$ upstream of the delta (Khuhawar et al., 2005); and (iii) at lakes recharged by the Indus (Jahangir et al., 2000). All three researchers independently reported that the total suspended and dissolved contents were contributed to by erosion of the riverbed. Aslam (2008) reported elevated levels of $\mathrm{Pb}$ and $\mathrm{Cd}$ in Indus river catchments and contents of $\mathrm{Cu}, \mathrm{Co}, \mathrm{Ni}$, and $\mathrm{Zn}$ that did not exceed WHO thresholds.

Karachi draws its water supply from lakes charged by the Indus. Although the amount of potable water available for food production is scarce, a large, unorganized vegetable production sector has emerged. Much of the irrigation water available to vegetable production is contaminated to some degree. The composition of soils in the boundaries of Karachi and its industrial area, separated by $25 \mathrm{~km}$, was sampled at four sites of the Korangi Industrial Estate and one at Karachi University was determined (Rehman et al., 2009). They reported that between the two areas there was a two-fold variation of $\mathrm{CaCO}_{3}$; three fold differences in organic matter, coarse sand content varied by $4 \%, \mathrm{pH}$ ranged between 7.8-8.4, and $\mathrm{Cu}, \mathrm{Zn}$ and $\mathrm{Cr}$ had concentration of $0.002-0.0741,0.003-0.09$, and 1.4$6.8 \square \mathrm{g} \cdot \mathrm{g}^{-1}$, respectively. The industrial area adjoins the present study area and these values have been used as reference values on the composition of Karachi soil. The objective of this study was to determine concentrations of possible contaminants in water, soil and tissues of vegetable crops irrigated with industrial waste water and treated water.

MATERIALS AND METHODS: The study area consisted of Karachi and environs. There are two large industrial areas in which textiles, polymers, chemicals, detergents, finished leather; refined oil and steel are produced. The bulk of the untreated industrial effluents are mixed with sewage which is used to irrigate vegetables.

The samples of industrial waste water (IWW), soil and crops were taken from the area adjoining Korangi Industrial Area; the location is $10 \mathrm{~km}$ south east of Karachi University. The IWW samples were not mixed with residential waste water. Water samples, along the loop linking the main IWW channel with farms, were collected in capped Teflon bottles, which had been pre-cleaned with detergent and rinsed with tap water and de-ionized water. During sampling, bottles were rinsed three times with 
sampled water and filled at a depth of one meter below the surface at six sampling sites $10 \mathrm{~m}$ apart and capped. Conductivity, dissolved oxygen, total dissolved solids and $\mathrm{pH}$ were measured on site. Samples were labeled and transported to the laboratory and stored overnight in the refrigerator at about $4^{\circ} \mathrm{C}$ prior to analysis.

The source of TW is the water treatment plant of Karachi Water and Sewerage Board where raw water is treated with alum and chlorinated. Karachi City Government supplies the treated water (TW) for drinking. The root vegetables beet (Beta vulgaris L.), potato (Solanum tuberosum L.), radish (Raphanus sativus L.) and associated soils were sampled. Each vegetable was sampled at 6 places across a hectare of randomly selected farms at each sampling site, varying in size 1-2 ha. The soil sample was scooped from the same spot as the vegetable sample. Each sample was portioned into six aliquots for replicate runs and statistical evaluation. The TW was used to irrigate all crops for 13 weeks at the soil adjoining the laboratory, about $3 \mathrm{~km}$ west of Karachi University. Treated water samples were taken directly from the tap. The mode of TW soil and vegetable sampling was the same as for IWW treated crops.

Water samples were cleared of organic matter by wet ashing method (Radojevic and Bashkin, 1999). Five hundred-mL samples of wastewater were evaporated to $20 \mathrm{~mL}$ on a hot plate and $5 \mathrm{~mL} \mathrm{HNO}_{3}$ added; heating continued with $\mathrm{HNO}_{3}$ being added until the solution cleared. The analyte solution was filtered, insolubles were removed and the volume made up to $100 \mathrm{~mL}$ with deionsed water. Samples were analyzed with an Atomic Absorption Spectrophotometer (PE 2380, Norwalk, VT) equipped with a thermal atomizer, air-acetylene flame, autosampling and autodilution. External calibration was used for quantitative analysis.

Vegetable samples were washed with distilled and de-ionized water to remove soil particles from the surface dehydrated at $80^{\circ} \mathrm{C}$ for $48 \mathrm{~h}$ and pulverized. Tissues were dissolved in $5 \mathrm{~mL}$ of $\mathrm{HNO}_{3}$ and wet ashed as for water samples. Samples were cooled and filtered through Whatman no. 42 filter paper into a $100 \mathrm{~mL}$ Erlenmeyer flask and made up to mark with de-ionized water. Soil samples were dried in an oven at $80 \square \mathrm{C}$ for $24 \mathrm{~h}$. Each sample was dissolved in 5 $\mathrm{mL} \mathrm{HNO}_{3}$ and wet ashed as for water samples. The $\mathrm{pH}$ of water samples was measured with a precalibrated $\mathrm{pH}$ meter (TS-1, Suntex, Taiwan) with combined glass and internal reference electrodes. Electrical conductivity of water samples was measured with a conductivity meter (120 Orion, Houston, TX) calibrated with $\mathrm{KCl}$ solution. Ambient temperature of the sampling location at a $1 \mathrm{~m}$ depth and of the water sample was measured with a mercury thermometer (Table 1). A $50 \mathrm{~mL}$ volume of the sample was filtered through weighed Whatman no. 42 filter paper. Insoluble substances on the filter paper were washed with 20 to $30 \mathrm{~mL}$ of de-ionized water. The filter paper was dried along with the insoluble substances affixed to it in an oven at 100 to $110 \square$ C. The filter paper was weighed after drying and cooling, and the amount of suspended solids calculated in $\mathrm{mg} \cdot \mathrm{L}^{-1}$ from the weight difference.

Total dissolved solids (TDS) in water samples were evaluated by filtering $50 \mathrm{~mL}$ of the sample. The filtrate was placed in pre-weighed glass dishes that were oven dried at $110 \square \mathrm{C}$ for $2 \mathrm{~h}$. Dishes were weighed after drying and amounts of TDS calculated and expressed as $\mathrm{mg} \cdot \mathrm{L}^{-1}$ from the weight difference. A $10 \mathrm{~mL}$ water sample was titrated against a $0.02 \mathrm{M}$ standard $\mathrm{HCl}$ to a pinkish end point using methyl orange as an indicator (Salami and Egwin, 1997) to determine alkalinity. A $10 \mathrm{~mL}$ water sample was passed through cation exchange resin and the effluent titrated with $0.02 \mathrm{M} \mathrm{NaOH}$ using phenolphthalein indicator (Salami and Egwin, 1997) to determine acidity. Water hardness was measured by complexometric titration at $\mathrm{pH} 10$ adjusted with $\left(\mathrm{NH}_{4} \mathrm{NO}_{3}-\mathrm{NH}_{4} \mathrm{OH}\right)$ buffer solution. Titration was carried out with disodium salt of ethylenediamine tetra acetic acid $\left(\mathrm{Na}_{2}\right.$ EDTA. $\left.2 \mathrm{H}_{2} \mathrm{O}\right)$ using Eriochrome black-T as the indicator. Color change from wine-red to blue was the end point (Salami and Egwin, 1997). Sulfate concentration in the water samples was determined by titration (Rand et al., 1976). Chloride concentration in water samples was determined spetrophotometrically at $\lambda_{515} \mathrm{~nm}$ (Rand et al., 1976), with the color indicator N, N-diethyl-p-phenylenediamine. A $100 \mathrm{~mL}$ sample was placed in each of 5 BOD bottles; one pellet of lithium hydroxide was placed inside the cap of each bottle before tightly recapping and all bottles were shifted to a biological oxygen demand (BOD) monometer (DR 2010,Hach, Loveland, CO), started at zero mercury level, and stored at $20 \square \mathrm{C}$ for 5 days. BOD levels were ascertained from mercury scales affixed on each bottle (Aslam, 2009). For chemical oxygen demand (COD) the absorbance of a $2 \mathrm{~mL}$ sample was added to a reagent (conc. 0-15 g. $\mathrm{L}^{-1}$ ) vial; digested in a COD reactor (DR 2010 Spectrophotometer, Hach) at $150 \square \mathrm{C}$ for $2 \mathrm{~h}$; aerated for a few minutes at room temperature and measured at $\lambda_{250} \mathrm{~nm}$ on a spectrophotometer against a reagent blank vial containing distilled, deionized water. Dissolved oxygen (DO) was measured with direct immersion of a DO probe into the sample solution. 
RESULTS AND DISCUSSION: The mean values of physicochemical characteristics of treated water (TW) and industrial waste water (IWW) are summarized in Table-1. There were differences in physicochemical properties of TW and IWW. The IWW was less alkaline than TW. IWW was twice as hard; 1.5 times more acidic, had 1.5-times more dissolved load than TW; suspended solids in TW constitute $13 \%$ of total solids and $11 \%$ of total solids in IWW. A significant change was observed in the values of electrical conductivity (EC). A comparison of $\mathrm{pH}$, TDS and $\mathrm{EC}$ of IWW, TW indicates more free metal availability in IWW than in TW because of their dissociation at lower $\mathrm{pH}$ from organic matter. Sulphates and chlorides contents remained below WHO tolerance levels. There was a significant increase in BOD and COD values in IWW and TW but a corresponding decrease in DO due to precipitation of nutrients associated with organic matter brought in by the urban sewage.

\begin{tabular}{|c|c|c|c|}
\hline Characteristic & Treated water & Industrial waste water & WHO standards \\
\hline Ambient Temperature $\left({ }^{\circ} \mathrm{C}\right)$ & 26 & 28 & $\mathrm{DNA}^{\mathrm{a}}$ \\
\hline $\mathrm{pH}$ & 8.20 & 7.62 & $6.5-8.5$ \\
\hline Conductivity $\left(\mu \mathrm{s} \cdot \mathrm{cm}^{-1}\right)$ & 644 & 1959 & 750.5 \\
\hline Temperature $\left({ }^{\circ} \mathrm{C}\right)$ & 30.5 & 30 & 21 \\
\hline Suspended solids $\left(\mathrm{mg} \cdot \mathrm{L}^{-1}\right)$ & 114 & 154 & 25 \\
\hline Dissolved solids $\left(\mathrm{mg} \cdot \mathrm{L}^{-1}\right)$ & 772 & 1242 & 1000 \\
\hline Total solids $\left(\mathrm{mg} \cdot \mathrm{L}^{-1}\right)$ & 886 & 1396 & DNA \\
\hline Alkalinity $\left(\mathrm{mg} \cdot \mathrm{L}^{-1}\right.$ as $\left.\mathrm{C} \mathrm{aCO}_{3}\right)$ & 320 & 570 & 200 \\
\hline Acidity $\left(\mathrm{mg} \cdot \mathrm{L}^{-1}\right.$ as $\left.\mathrm{CaCO}_{3}\right)$ & 20 & 30 & DNA \\
\hline Hardness $\left(\mathrm{mg} \cdot \mathrm{L}^{-1}\right.$ as $\mathrm{CaCO}_{3}$ ) & 95 & 155 & DNA \\
\hline $\mathrm{SO}_{4}^{-2}\left(\mathrm{mg} \cdot \mathrm{L}^{-1}\right)$ & 28.8 & 76.8 & 250 \\
\hline $\mathrm{Cl}^{-}\left(\mathrm{mg} \cdot \mathrm{L}^{-1}\right)$ & 40 & 62.67 & 250 \\
\hline $\mathrm{BOD}\left(\mathrm{mg} \cdot \mathrm{L}^{-1}\right)$ & 280 & 362 & 100 \\
\hline $\mathrm{COD}\left(\mathrm{mg} \cdot \mathrm{L}^{-1}\right)$ & 130 & 176 & DNA \\
\hline $\mathrm{DO}\left(\mathrm{mg} \cdot \mathrm{L}^{-1}\right)$ & 7.8 & 6.6 & 9.2 \\
\hline
\end{tabular}

Metal presence also differs in TW, IWW and in the soils treated by these types of water (Table-2). The level of $\mathrm{Cd}\left(5.85 \mathrm{mg} . \mathrm{L}^{-1}\right)$ was highest in IWW soil and it was 100 fold less in IWW $\left(0.059 \mathrm{mg} . \mathrm{L}^{-1}\right) . \mathrm{Cr}$ (84.5mg. $\left.\mathrm{L}^{-1}\right)$ presence in IWW soil was 186 times higher than in IWW. Mn (480.3mg. $\left.\mathrm{L}^{-1}\right)$ was also highest in IWW soil than TW soil $\left(2.672 \mathrm{mg} . \mathrm{L}^{-1}\right)$. Its level was 28 times higher in IWW than TW. Zn (305mg. $\mathrm{L}^{-1}$ ) was similarly highest in IWW soil than IWW.
Sampling source also affected levels of metals. Of the two water types IWW had higher metal levels than TW source. This comparison also had exceptions; $\mathrm{Cr}$ was higher in TW than IWW. The soil seems to accumulate heavy metals (Table-2). In TW the order of contents was $\mathrm{Cd}, \mathrm{Mn}, \mathrm{Cr}, \mathrm{Zn}$; in IWW it was: $\mathrm{Cd}$, $\mathrm{Cr}, \mathrm{Zn}, \mathrm{Mn}$, in TW soil it was: $\mathrm{Cd}, \mathrm{Cr}, \mathrm{Zn}, \mathrm{Mn}$ and in IWW soil it was: $\mathrm{Cd}, \mathrm{Cr}, \mathrm{Zn}, \mathrm{Mn}$.

Table 2: Metal levels in water and soil samples, $\mathrm{n}=6\left(\mathrm{mg} \cdot \mathrm{L}^{-1}\right)$

\begin{tabular}{lcccc}
\multicolumn{5}{c}{ Table 2: Metal levels in water and soil samples, $\mathrm{n}=6(\mathrm{mg} \cdot \mathrm{L})$} \\
& $\begin{array}{c}\mathrm{Cd} \\
\text { Mean } \pm 2 \mathrm{~S}\end{array}$ & $\begin{array}{c}\mathrm{Cr} \\
\text { Mean } \pm 2 \mathrm{~S}\end{array}$ & $\begin{array}{c}\mathrm{Mn} \\
\text { Mean } \pm 2 \mathrm{~S}\end{array}$ & $\begin{array}{c}\mathrm{Zn} \\
\text { Mean } \pm 2 \mathrm{~S}\end{array}$ \\
\hline Treated water (TW) & $0.005 \pm 0.0024$ & $0.510 \pm 0.008$ & $0.070 \pm 0.006$ & $0.830 \pm 0.008$ \\
\hline $\begin{array}{l}\text { Industrial waste water } \\
\text { (IWW) }\end{array}$ & $0.059 \pm 0.006$ & $0.455 \pm 0.008$ & $1.980 \pm 0.038$ & $1.950 \pm 0.070$ \\
\hline
\end{tabular}

KOUSAR YASMEEN; MUHAMMAD ALI VERSIANI; RAFEE ARAIN; QAMARUL HAQUE; NASIRUDDIN KHAN; SYED ASGHAR ALI ; AASHIQ ALI LANGHA 


\begin{tabular}{lcccc}
\hline TW treated soil & $0.007 \pm 0.004$ & $0.128 \pm 0.004$ & $2.672 \pm 0.008$ & $0.714 \pm 0.004$ \\
\hline IWW treated soil & $5.850 \pm 0.016$ & $84.500 \pm 0.418$ & $480.30 \pm 0.358$ & $305.00 \pm 0.912$ \\
\hline & & & \\
\hline
\end{tabular}

The probable explanation of the retention of metal load by the soil is the nature of Karachi's loam soil (Atiq-ur-Rehman et al., 2009). The retention is accompanied by a concurrent enrichment of organic matter (OM) chipped in by IWW and an increase in the water holding capacity of the soil. Another synergetic effect comes from the substantial presence of $\mathrm{CaCO}_{3}$ in the soil that keeps water $\mathrm{pH}$ alkaline and bulk of the heavy metals bonded to organic matter, but at any given time during the watering period a decrease in $\mathrm{pH}$ due to quality of IWW seems to occur that frees the metals from $\mathrm{OM}(\mathrm{Mn}, \mathrm{Zn}$, and $\mathrm{Cr}$ ) get dissolved in water, reach root tissues and get absorbed. The data on metal presence in vegetable (Table-3) may be linked both to the irrigation source and the tissue absorption ratio.

Table 3: Comparison of metal levels of vegetables grown on TW and IWW $\mathrm{n}=6\left(\mathrm{mg} \cdot \mathrm{L}^{-1}\right)$

\begin{tabular}{lccccc}
\hline Vegetable & $\begin{array}{c}\text { Water Type used for } \\
\text { irrigation }\end{array}$ & $\begin{array}{c}\mathrm{Cd} \\
\text { Mean } \pm 2 \mathrm{~S}\end{array}$ & $\begin{array}{c}\mathrm{Cr} \\
\text { Mean } \pm 2 \mathrm{~S}\end{array}$ & $\begin{array}{c}\text { Mn } \\
\text { Mean } \pm 2 S\end{array}$ & $\begin{array}{c}\text { Zn } \\
\text { Mean } \pm 2 S\end{array}$ \\
\hline Beet & Treated & $0.001 \pm 0.002$ & $0.150 \pm 0.104$ & $0.210 \pm 0.056$ & $0.920 \pm 0.156$ \\
& IWW & $0.120 \pm 0.056$ & $0.320 \pm 0.084$ & $0.030 \pm 0.022$ & $0.060 \pm 0.042$ \\
\hline Potato & Treated & $0.002 \pm 0.002$ & $0.240 \pm 0.116$ & $0.170 \pm 0.038$ & $0.710 \pm 0.048$ \\
& IWW & $0.330 \pm 0.060$ & $0.060 \pm 0.052$ & $0.020 \pm 0.022$ & $0.040 \pm 0.028$ \\
& Treated & $0.002 \pm 0.004$ & $0.120 \pm 0.034$ & $0.080 \pm 0.080$ & $0.700 \pm 0.358$ \\
\hline Radish & IWW & $0.260 \pm 0.112$ & $0.040 \pm 0.028$ & $0.860 \pm 0.080$ & $0.180 \pm 0.064$
\end{tabular}

*Confidence level 95\%; $P \leq 0.05, \mathrm{n}=$ number of samples, $\mathrm{s}=$ standard deviation

A quantitative reading of Table-3 indicated four metal levels $(\mathrm{Cd}, \mathrm{Cr}, \mathrm{Mn}$ and $\mathrm{Zn})$ in vegetables irrigated separately with both types of water. Level of Cd was higher in all vegetables irrigated with IWW than TW. Cd in vegetables irrigated with IWW crossed the limits of WHO. The highest level of $\mathrm{Cd}$ was found in potato $\left(0.33 \mathrm{mg} . \mathrm{L}^{-1}\right)$ irrigated with IWW. The mean concentrations (mg. $\mathrm{L}^{-1}$ ) of $\mathrm{Cd}$ in beet, potato and radish irrigated with treated water were $0.001,0.002$ and 0.002 respectively, $\mathrm{Cr} 0.15$, $0.24,0.12$, Mn 0.21, 0.17, 0.08 and $\mathrm{Zn} \mathrm{0.92,} 0.71$ and 0.70 respectively in these vegetables. Whereas in industrial waste water irrigated vegetables $\mathrm{Cd}$ was $0.12,0.33$ and 0.26 respectively, Cr $0.32,0.06,0.04$, Mn 0.03, 0.02, 0.86 and $\mathrm{Zn} \mathrm{0.06,} 0.04$ and 0.18 respectively. The higher concentration of $\mathrm{Cr}$ and $\mathrm{Mn}$ was found in IWW beet and radish respectively while $\mathrm{Zn}$ in TW beet.

Irrigating vegetables with IWW should certainly be discouraged as it contaminates and exhausts the soil retention's and exchange capacity irreversibly and when has lower $\mathrm{pH}$ raises the risk of transferring part of the heavy metal load to the root tissues. The quality of TW, which is allowed to be ingested by humans, needs better monitoring since it contains elevated levels of $\mathrm{Cd}, \mathrm{Cr}, \mathrm{Zn}$ and $\mathrm{Mn}$. The fate of heavy metal contaminants of irrigation water may be different for soils having composition and retention capacity different from that in this study.

\section{REFERENCES}

Agusa, T., Kunito, T., Fujihara, J. and Kubota, R., (2006). Water manganese exposure and children's intellectual function. Environ. Pollut.139: 95-106.

Akan, J.C., Abdulrahman, F.I., Ayodele , J. T. and Ogugbuaja,V.O., (2007). Studies on the effect of municipal waste and Industrial effluent on the pollutant levels of River Challawa, Kaon State, Nigeria. Res. J. Appl. Sci. 2(4): 530-535.

Aslam, M., Khuhawar, M.Y. and Rafee, A., (2009). Hydrochemical profile of Banjosa Lake

Poonch, Kashmir. Asian J. Chem. 21(5): 3651-3659.

Jahangir, T. M. and Khuhawar, M. Y., (2000). Some studies on water quality and biological life at Kinjhar and Haleji Lakes of District Thatta, Sindh, Pakistan. Pak. J. Biol. Sci.3 (11): 1965-1972.

Jameel, A.A. and Sirajudeen. I., (2006). Risk assessment of physico-chemical contaminants in groundwater of Pettavaithalai area, Tiruchirappalli, 
Tamilnadu-India. Environ Monit Assess. 123(1-3): 299-312.

Khuhawar, M.Y., Das, P. and Dewani, V. K., (2005). Sediment analysis of sewage contaminated canal. J. Chem. Soc. Pak. 27: 160-162.

Mirza, M. A., Khuhawar, M. Y. and Rafee, A., (2007). Quality of spring water in the catchment areas of the Indus River. Asian J. Chem.19 (7): 5279 5304.

Radojevic, M. and Bashkin,V. N., (1999). Practical environmental analysis. The Royal Soc. Chem. Cambridge, UK.

Rand, M.C., Chain, C.F., Arnold, E. and Greensburg, A., (1976). Standard methods for the examination of water and waste water. $14^{\text {th }}$ ed. American Public Health Association, American Water Works Association, Water Pollution Control Federation, Washington D.C.
Rand, M.C., Chain, C.F., Arnold, E. and Greenburg, A., (1995). Standard methods for the examination of water and waste water. $17^{\text {th }}$ ed. American Public Health Association, American Water Works Association and Water Pollution Control Federation, Washington, D.C.

Rehman, S. A. and Iqbal, M. Z., (2009). Peltophorum pterocarpum (DC.) Baker Ex K. Heyne growth in soils of Korangi and Landi Industrial areas of Karachi. Pak. J. Basic Appl. Sci. 5(1): 7-16.

Salami, S.J. and Egwin, I.N., (1997). Impact of tannery effluents on the quality of receiving stream. Afr. J. Natural Sci. 2: 1

World Health Organization (WHO), (2004). Guidelines for drinking-water quality, $3^{\text {rd }}$ ed., Vol. 1. World Health Organization. Geneva, Switzerland. 